This item was submitted to Loughborough's Research Repository by the author.

Items in Figshare are protected by copyright, with all rights reserved, unless otherwise indicated.

\title{
Competence understanding and use in SMEs: a UK manufacturing perspective
}

PLEASE CITE THE PUBLISHED VERSION

http://dx.doi.org/10.1080/00207541003738873

PUBLISHER

(c) Taylor \& Francis

VERSION

AM (Accepted Manuscript)

LICENCE

CC BY-NC-ND 4.0

REPOSITORY RECORD

Bhamra, Ran S., Samir Dani, and T.A. Bhamra. 2019. "Competence Understanding and Use in Smes: A UK Manufacturing Perspective”. figshare. https://hdl.handle.net/2134/13110. 


\title{
Competence understanding and use in SMEs: \\ A UK manufacturing perspective
}

\author{
Ran Bhamra \\ Wolfson School of Mechanical and Manufacturing Engineering \\ Loughborough University, Loughborough, LE11 3TU, UK. \\ Samir Dani \\ Business School, Loughborough University, Loughborough, LE11 3TU, UK. \\ Tracy Bhamra \\ Department of Design and Technology \\ Loughborough University, Loughborough, LE11 3TU, UK.
}

\begin{abstract}
The paper seeks to address the neglected area of competency research that is the understanding and application of core competency concepts within Small and Medium sized enterprises (SMEs). There is little doubt that SME manufacturing organisations can possess core competencies, however it appears from the literature that this issue has not yet been adequately addressed nor is there a clarification with regards to the nature of these competencies. This paper presents the results of an exploratory research study conducted with UK SMEs. The organisations involved were diverse and included a medical products manufacturer, automotive supplier, large metal fabrication and electromechanical capital equipment integrator. This research provides an insight into how competency concepts are perceived and understood amongst SME manufacturing firms and also whether these organisations use competence concepts. The research findings are important for both practitioners and academics, indicating an apparent lack of connectedness between research into competence and its 'real world' understanding and practical use within manufacturing
\end{abstract} SMEs.

Keywords Core competence, Manufacturing, SME, Sustainable Competitive Advantage, Resource-Based View 


\section{$1.0 \quad$ Introduction}

The concept of core competencies has gained popularity in the business and academic world since the publishing of the landmark article on core competency by Prahalad \& Hamel (1990). It was Selznick (1957) who originally used the term 'distinctive competence' to describe that feature of an organisation its competitors did not possess. Core competencies are important to organisations because they can enable enhanced value creation and subsequently, an ongoing profitable business (Newbert, 2008). The ideas of core competency are very closely related to the so-called 'resource-based view' of the firm. The resource-based view can be seen as an alternative approach towards strategy, where the dominant convention had been the Competitive Positioning approach as championed by Porter (1980). Porter, as an industrial organisational theorist affirms the central view as being that a firm's performance is based on the industrial environment it finds itself operating within. With Porter's (1980) competitive positioning approach to strategy determination, the competitive forces in the industry are analysed and known as an ‘outside-in’ approach.

Within the emerging resource-based view of the firm, the belief is that a competitive advantage arises from a strategy based upon the usage of special, rare and tacit 'bundles of resources' held within the boundary of an organisation, Barney (1991), Grant (1991), Peteraf (1993), Wernerfelt (1984), Rumelt (1984) and Penrose (1959). The resource-based view of the firm however, acknowledges the economic argument from the competitive environment arena that external forces should also be considered. With the rising popularity of core competencies and their related concepts of key and distinctive capabilities, there is an emerging picture that a potentially very large percentage of manufacturing industry has only a loose understanding and appreciation of this relatively new approach of thinking about 
competitive strategy (Bhamra \& Baines, 2002). Petts (1997) notes that there has been little application of competence concepts to SMEs, and Mills et al (2003) note a lack of empirical research in the resource based arena. In addition to this, anecdotal evidence (from the authors' and colleagues' broad experience from industry and consultancy) suggests that many practitioners hold to a misconception that a core competency is simply what they are 'good' at. However, this is not what the writers in the field purport (Prahalad \& Hamel, 1994, Gallon et al, 1995). Hamel \& Prahalad, (1994) and also Coyne, (1986) say that a central aspect of core competency is something that helps to provide a 'sustainable competitive advantage (SCA)' for the firm that harbours it - thus enabling a business success over a long period of time. Prahalad and Hamel's (1994) famous, if difficult to grasp, definition of core competence is:

“...(core competence's are) the collective learning in the organisation especially how to co-ordinate diverse production skills and integrate multiple streams of technologies.”

Coyne (1986) defined sustainable competitive advantage as:

“(SCA) is exclusively concerned with defeating competitors and achieving dominance in a product/market segment. It is thus - in concept, and usually in practice - a subset of business strategy, which addresses the broader goal of maximising the wealth of shareholders”.

The implication being that it is something a firm does considerably better than its competitors or, that it possesses something relatively unique. Some researchers have tried to incorporate resource based and competence concepts into their work such as, for example, De Toni \& Tonchia (2002), Zhang et al (2002) and also Reiner et al (2006). Other recent research studies demonstrate a positive correlation between organisations that employ resource based 
or competence thinking within a manufacturing environment and organisational performance Ahuja \& Khamba (2008), Corbett (2008) and also Yeung et al (2007).

This paper documents research conducted to investigate the existence and nature of core competency concepts within a section of UK SME manufacturing organisations. The investigation was based on a survey of 16 organisations. The main contribution resulting from this research is that it, for the first time, explores what senior managers within the manufacturing industry think about core competency concepts.

The paper is structured in the following manner; the next section is background and describes earlier work from within the field. This is followed by the research aim and method section that explains the 'what', 'why' and 'how' of this study. The results from the research are then presented, followed by a detailed discussion that summarises the main findings. Finally, conclusions are drawn.

\subsection{Background}

The concept of competence as described in the much of the core literature, for example (Prahalad \& Hamel, 1994, Selznick, 1957, Penrose, 1959, De Meyer \& Kim, 1996) places core competency thinking and core competency strategy squarely within the scope of corporate level strategy where the concern regards the wider business portfolio, markets and geographic locations. Although there are seminal papers that originate as far back as the 1950s, the field of core competency research is relatively new since most contributions have been during the late 1980s and early 1990s. This can provide a limited consensus from which to build a common view. Although the overall picture is essentially the same, there are some 
elements that writers in the field disagree on such as meanings and definitions, in particular, capability and competence. For instance, Kay (1993) talks about his three types of 'distinctive capability' as being corporate architecture, reputation and innovation, where they broadly adhere to Barneys (1991) rules of being difficult to build, imitate and codify.. Stalk et al (1992) speak simply of 'capabilities' which they describe as "a set of business processes strategically understood--for example, Wal-Mart's expertise in inventory replenishment... Such capabilities are collective and cross-functional--a small part of many people's jobs, not a large part of a few”. Success for Stalk et al (1992) derives from selecting the right capabilities to build, manage and exploit. Although there are many similarities, there are of course subtle differences between these definitions which merely add to the confusion in terminology. An interesting point to note is that in discussing the great success in recent times of the Canon company within the USA, Kay (1993), Prahalad and Hamel (1994) and Stalk et al (1992) all attribute slightly differing explanations for this phenomenon.

The model of the core competency hierarchy is shown in figure 1 below. The model is based on the general literature in the area and in particular Prahalad and Hamel (1994), Javidan (1998) and Gallon et al. (1995).

\section{Figure 1}

With reference to the model above, the core competency hierarchy firstly, and most clearly, states that core competencies exist at the corporate level of organisational business strategy. These core competencies are built up from certain competencies that reside in different Strategic Business Units (SBU). Core competencies can come about through the crossbusiness interactions across a multi-business organisation. The competencies are themselves 
resultant from the cross-functional interactions within each business unit, the building blocks of which are the capabilities of the business, that are the processes and routines. The lowest form of building block, and one that directly contributes to capabilities, is the resource. A resource can be physical, human or organisational in nature (Barney, 1991). Barney (1991) asserts that in order for an organisation to be able to achieve a sustainable competitive advantage, resources must be considered valuable, rare, inimitable and non-substitutable (Barney's so-called VRIN characteristics). By their nature core competencies are difficult to assess because as one looks 'up' the organisational hierarchy, the more complex and intangible they appear to be. . In Figure 1, the arrows that emanate from the corporate level 'peak' indicate that core competencies enable application to different markets.

Related, previous research by Baines and Kay (2001) raised questions about what practitioners actually believed core competencies to be. In this work, $10 \%$ of respondents to their survey, said that they had defined core competencies for their organisation, meaning presumably, that they possessed them (or believed they did). In addition to having claimed core competencies, a number of respondents further stated their belief that some of their core competencies resided within their manufacturing function. It is possible that the respondents are referring to what some authors have called 'distinctive manufacturing competencies' (Hayes \& Wheelwright, 1979, Vickery, 1993, Schroeder et al, 1986, Kim \& Arnold, 1992). Distinctive manufacturing competencies are a feature of some leading manufacturing based organisations that have helped to provide them with a competitive advantage. Distinctive manufacturing competencies, however, reside at the functional level. By definition, distinctive manufacturing competencies are not the same thing as core competencies. 
Seminal literature (Prahalad \& Hamel, 1994, Barney, 1991, Grant, 1991, Peteraf, 1993) emphasises the intangibility of core competencies and the great efforts which may be required to identify them within an organisation. In fact, methods known to exist for the identification of core competencies (of which there are few) mostly tend to be high level guidelines describing an 'approach’ rather than detailed methodologies (Table 1). Table 1 shows various work completed in the competency and resource field of strategy with regards to frameworks, models and methods.

\section{Table 1}

In relation to the information in Table 1 above, the empirical studies and examples of core competencies (Armstrong \& Shimizu, 2007) have focussed on large organisations, and hence guidelines, tools and methods refer to large organisations (Prahalad \& Hamel, 1994, Gallon et al, 1995, Winterschied, 1994). The reasons for this research focus on large organisations is not clear. There is no evidence from literature suggesting that core competency concepts should not be equally relevant to organisations which are not large or multi-national. Petts (1997) is one author who has tried to relate the core competency concept to SMEs, with a conceptual framework. An additional gap in research has also been identified by Mills and Platts (2001) who note that there:

“..has been an emphasis on competencies and capabilities at a corporate level with little detail on the resources on which they depend or how they were formed or acquired". 
Although industrial examples of organisations that have apparently had great and continued success on the basis of competencies tend to focus on the technologically advanced and heavily resourced ones (i.e. Sony, Black and Decker, and Honda), no examples have been found from within the SME sector, except for the recent article by Corbett (2008). This raised the fundamental question of how would SMEs, who claimed to posses core competencies, have defined them and what would they be In earlier research on SME competitiveness, Corbett and Campbell-Hunt (2002) investigated how organisations might create capabilities that lead to competitive advantage. SME competitivness research was also conducted by Laglace and Bourgault (2003) who looked at long term sustainability of businesses and the impact of government programmes in assisting SMEs to improve manufacturing practice. Bessant et al (2001) considered agility as a major influence on competitive advantage within SMEs where core competence was seen as one of a triad of key elements, the others being strategy and behavioural characteristics.

\subsection{Research Aim and Methodology}

\subsection{Research Aim and Questions}

As the previous section illustrates, there was a research imperative to explore the role of core competency concepts within manufacturing SMEs. The aim of this study was to investigate manufacturing practitioners' level of understanding of core competency concepts and their use. The two research questions below formed the basis for advancing this aim.

1. What do practising managers of UK manufacturing organisations understand about core competency concepts? 
2. Is there any evidence that UK manufacturing organisations use core competency concepts within their businesses?

\subsection{Research Methodology}

The research being exploratory in nature, it was decided to conduct the research using qualitative research techniques. 32 organisations, which comprised of SMEs and large companies were initially contacted for interviews. The reason for including the large companies was to have an insight into how much the perspectives regarding competencies, differed between SMEs and the large companies.From the contacted sample of companies, 16 responded positively and agreed to be interviewed (Table 2 below). Out of these 16 organisations, 5 were large and 11 were SME in size. One senior manager from each organisation was interviewed. Due to the strategic nature of the questions, senior managers were mainly targeted, i.e the managing director or manufacturing manager/ director were interviewed.

\section{Table 2}

The data collection comprised of a plant tour to observe the process and get a better understanding of the company, and a semi-structured interview session. The interview session was closely related to addressing the research questions. Care was taken to ask relevant questions in such a way as not to bias respondents' answers or allude to an answer. Open questioning was a main feature of the interviews. The content of the interview required questions to unearth facts, beliefs and behaviour and adhered to good interview practice guidelines as set down by Robson (1993). 
Each meeting was structured so that first a plant tour was taken in order to observe first hand what the facility looked and 'felt' like - important as a secondary means of data collection. The plant observation also enabled the researcher to compare issues between what was observed and what was discussed in the interview. The interview session itself was comprised of four parts. The first part contained contextual questions related to basic facts about the organisations such as industry sector, number of employees and so on. The second part was concerned with the organisation's business strategy, where questions focussed on the overall business direction, where they were 'coming from' and how this related to what was required from, in particular, their manufacturing function. The third part focused on core competencies and aimed to gain an insight into the practitioner's thoughts before going deeper by asking questions relating to the understanding of the concepts. The fourth part of the interview explored the extent of practitioner knowledge and use of tools and techniques relating to core competencies. The interview session ended with the interviewees completing a short checklist related to manufacturing competence (Kim \& Arnold, 1992) which was intended to provide a fuller picture about the relationship between the organisations manufacturing and business strategies.

\subsection{Data analysis}

The data from semi structured interviews was analysed using 'contact summary sheets' as suggested by Miles and Huberman (1984). Relevant units of meaning were extracted from each session. These units were in the form of quotes, words, examples and incidents (as a complete unit). These units were clustered into themes, which were referenced again from the literature review. The themes were then reviewed again to cluster them further which resulted in three emerging themes. 


\subsection{Results}

The two research questions which motivated this study were about practitioners 'understanding' and practitioners 'use' of competency concepts. Table 3 below shows a sample of questions and respondents answers.

Table 3

Table 4 below shows the observations that were derived from full set of initial data. The observations were fact based and objective.

Table 4

\subsection{Emerging Themes}

Theme

T1 Poor Understanding of concepts Practitioners have an very poor understanding of competency concepts.

T2 No awareness of available tools The use of competency concepts within the survey sample appears to be non-existent. Practitioners were unaware of any available tools.

T3 Belief in false core competencies Practitioners believed that they were successful due to their claimed core competencies.

\section{Observation number}

$6,7,8,10,11,12$

19

$13,14,15,16,17$ 


\subsection{Understanding of Competency Concepts}

Interviewees were asked what they knew about practical business tools for addressing core competency issues. Specifically, had their firm any experience of using methods or guidelines for identifying, assessing, developing or deploying core competencies. Secondly, if they had not used such tools, were they aware of their existence? In both instances, all respondents answered 'No', they had not used any competency related tools, nor were they aware of their existence.

\subsection{Use of Competence Concepts}

This area of questioning looked at how or where, those organisations that claimed to have a core competence were utilising it.

The applicability, or potential applicability, of a company's core competence to other markets was a key feature for Prahalad and Hamel (1994) in describing the nature of core competencies. The survey companies were asked if they believed that their stated core competencies could be (or were being) deployed in markets other than which they were originally used in. 63\% of all respondents (both SME and large) believed that their stated core competencies were or could be applied in different business areas.

The survey sample were asked if they thought (or indeed knew for certain) whether any of their competitors possessed similar core competencies to themselves. $69 \%$ of all respondents claimed to possess core competencies that were rare amongst their competitors. In addition the survey sample were asked whether they thought their stated core competencies were easy, difficult or impossible to imitate by those competitors that do not hold them. $69 \%$ of all 
sample respondents claimed to possess core competencies that were rare amongst their competitors.

\subsection{Discussion}

Through the research it was found that practitioners held a vague impression about their organisations apparent strengths. 50\% of all senior managers believed that there was something unique about their organisations, relative to the competition, and further, $88 \%$ of all organisations believed they possessed a core competency that was difficult to copy by any competitor. In reality, interviewees' purported competencies usually turned out to be manufacturing based capabilities such as 'carbon fibre processing skill'. This may be a clear advantage in competition but it is not enough to fulfil the characteristics for a core competency, as required by Prahalad and Hamels (1990) definition. The respondents considered core competencies as essentially those things that the firm was good at. Although this may be a key skill, it was unlikely to be their source of competitive advantage as their competitors also possessed it. Managers were placing too high a value on resources they believed to be 'core competencies' but in fact were not. Core competencies are all about providing a sustainable competitive advantage based on leveraging skills and knowledge that is exemplary amongst peer group companies (Barney, 1991, Prahalad and Hamel, 1990).

This research has shown that senior management in SMEs has a very poor understanding of what core competencies are and why they can be important to an organisation. The majority of managers questioned for this study could not readily or clearly state what their perceived core competencies were. This was unexpected since it contradicted what they had already stated earlier in the interview; that they had defined core competencies. The majority of managers in this study stated organisational functions such as R \& D, assembly, sales or a business attribute (i.e. ability to supply quality products, good financial controls) as their 
perceived core competence. This kind of language is vacuous and non-specific, it appears to echo a sales pitch one might make to a potential customer. When questioned about their organisation's core competencies, many senior managers mentioned such things as their production facility, assembly, purchasing knowledge, or even a specific process. None of these can be considered a core competency as described in the literature.

The research also found that SME practitioners are completely unaware of any available core competency tools and techniques. No interviewees were aware of any available tools or techniques which could be used to formally identify core competencies which may exist within their organisations. Additionally, an important fact was that no practitioner was aware of any tools or techniques that would guide them towards the development of potential core competencies. This may indicate either a lack of awareness or knowledge, or simply that such methods have not been well disseminated to practitioners. The reality is likely to be a combination both of these issues. An argument could be put forward that in industry, particularly SMEs, people simply do not have the time to learn these new methods or techniques which are by their nature, highly tacit and difficult to demonstrate. Emphasis and time is more likely expended on tools that can provide visible bottom-line differences and are short-term, for example lean tools. There is of course, much in the core competency arena that is conflicting and confusing (even for researchers) - possibly sending practitioners mixed messages. The issue of the plethora of definitions for instance (capabilities, competence, resources, strategic assets, distinctive capabilities and distinctive capabilities), being the prime case in point. 
With regard to the question of why core competencies are important, the interviewees did mention some of the accepted reasons such as providing a barrier to market entry and competitive advantage. The respondents understanding was put into focus however, when in amongst these legitimate statements were things such as "being successful” and "survivable”. There is clearly a lack of cohesive understanding about what core competencies really are and more importantly what their potential value is to the business. A common misunderstanding is the belief that a core competency is "something that we are good at". However, being good at something does not of course imply that it is better than the competition any more than it might provide the owner with above average profits and a sustainable competitive advantage.

Manufacturing functional strengths and capabilities alone are not always enough to provide a sustainable competitive advantage. However, positive infrastructural and cultural differences were also exhibited by some sample organisations as displayed by their openness, focus and professionalism. In fact, there is a remarkable similarity between what the authors observed during this exploratory study and what Hayes and Wheelwright (1984) attempted to explain when describing 'stage 4' of their 'four stage model of manufacturing's strategic role'. At 'stage 4' of their model, Hayes and Wheelwright (1984) state that the manufacturing function is influential at contributing to and pursuing the business strategy, new skills and technologies are acquired in anticipation of future competitive needs and that infrastructural elements (such as culture, employee relations and 'soft' systems) are a major characteristic. Since the focus of this research work has been manufacturing-based organisations it may be fair to argue that the respondents would unquestioningly search for manufacturing related core competencies. Likewise, in a survey of financial organisations, respondents may not look to production 
centred core competencies. This 'non-generalisability' is recognised and this study is sector specific.

Three very important accepted features of competence concepts were never mentioned nor effectively hinted at by any of the senior managers that were interviewed. These features, sustainability, non-substitutability (primarily from the resourced based view of the firm) and application of core competencies in other markets are of course important themes within the 'resource based view'. The interviewees never mentioned these when explaining their thoughts on the nature of core competencies. These are central to the competency concepts yet respondents either overlooked these in their comments, or which is more apparent, had no awareness of them. When considered in the light of the other answers, it is difficult not to conclude the latter point. This is a very important finding as it indicates a greater lack of awareness amongst practitioners regarding core competency concepts than originally imagined. The comparative element of this research was to compare the responses from the SME and large organisations. The results however, have clearly shown that there is no difference in concept understanding and use whether the organisation is large or SME in size, based on our survey sample. The results may or may not prove different with a larger sample size.

\subsection{Conclusions}

The theory behind core competencies and the strategies that take advantage of them is based on the premise that they are intangible and rare. If all of an organisation's competitors possess them, then they can never provide a legitimate or indeed sustainable competitive advantage, and by definition they are not core competencies. A small number of the surveyed organisations were clearly very successful within their commercial environments and were 
doing very 'good' things. However, this does not imply that their competition and environment may in time de-value their perceived product or service. Competency thinking forces organisations to look at the longer term future success and potential leadership of their chosen competitive field. The surveyed organisations appeared to concentrate on shorter-term strategies such as manufacturing process technology and techniques as opposed to consciously developing business areas for future competencies. Very little previous research was found regarding the applicability of core competencies to SME type organisations. However, Peteraf (1993) writing from the resource based perspective does acknowledge that resource based theory elements (such as those that form a basis for core competency concepts) are equally important for single businesses. The findings of this paper are valuable because for the first time, they describe the landscape of understanding and use of competency concepts within manufacturing based SMEs.

A major conclusion that emanates from this research is that there is a great interest in the idea of core competencies from within industry. The term 'core competence' has entered wide and common usage. However, and very importantly, there exists an apparent and deep lack of understanding and appreciation for core competency concepts within the surveyed firms. A major implication of this finding is that if these organisations do not have clear understanding of these concepts, they could never use them in building core competencies as part of organisational strategies. And where organisations do believe that they are something 'special' within their competitive environment, they are in fact relatively ordinary, something their competitors have or can potentially acquire with some effort. One strong reason for this is likely to be that competence concepts have not filtered down clearly to the industrial front line. At the present time the role of core competency concepts and the use of related strategies 
within SME manufacturing industry is confused, poorly understood and somewhat overshadowed by higher profile, practical business improvement tools (Lean, six-sigma and the like). This is not surprising in the light of the obvious lack of promotion and dissemination of effective practitioner focused research. Also, the concepts themselves can admittedly, be difficult to visualise due to their tacit nature. In the academic arena, one can find a number of tools and models (Table 1) however, their dissemination can be seen to have been ineffective into the 'real world' industrial, practitioner environment.

The limitations of this research have been primarily centred around the sample size. Although we initially set out to interview 32 respondents we were able to interview only 16, which is still 50 percent of the original sample. The research intended to be exploratory in nature, hence the data collected has been able to provide a rich picture of the perceptions that companies (senior managers) have regarding competencies. The research nor the findings were linked in any way to the firm's performance or the impact of the core competence on the competitive advantage of the firm. This will be a very important path to follow in the future and research the link between performance and competencies. In the context of this research the data has been sufficient to elicit an insight into how much the academic literature on core competency has percolated down to a practical level within manufacturing SMEs. With a view to further work in this area, the needs represented by the findings should be addressed i.e. practitioners want to understand core competency concepts and also how they could make effective use of them since the limited, existing work does not seem to be reaching them. Although there are a number of 'guidelines' available concerning how to identify and assess core competencies and why core competency thinking can be useful, not enough has been done in the area of relating the these concepts to the SMEs, which make up the vast majority 
of manufacturing industry. In particular, work should be done to help describe to practitioners how competency, including Resource Based View (Barney, 1994), concepts can fit into and assist the strategic outlook of their own organisations.

\section{Acknowledgements}

The underlying research contained in this manuscript was originally conducted in the Department of Manufacturing, Cranfield University. The financial support for the research project provided by Dr T Baines is gratefully acknowledged.

\begin{tabular}{|c|c|c|c|}
\hline & \multicolumn{3}{|c|}{ CORE COMPETENCES / CAPABILITIES / RBV } \\
\hline & FRAMEWORK & MODEL & METHOD \\
\hline $\begin{array}{l}\text { STRUCTURAL, } \\
\text { CONCEPTUAL }\end{array}$ & $\begin{array}{l}\text { Gilgeous \& Parveen K. } \\
(2001) \\
\text { Petts (1997) }\end{array}$ & $\begin{array}{l}\text { Baker et al (1997) } \\
\text { Bogner et al (1999) } \\
\text { DeMeyer \& Kim (1996) } \\
\text { Gilgeous \& Parveen K. } \\
\text { (2001) } \\
\text { Goddard (1997) } \\
\text { Peteraf (1993) } \\
\text { Scarborough (1998) } \\
\text { Savory (2006) }\end{array}$ & \\
\hline $\begin{array}{l}\text { IDENTIFY, } \\
\text { ANALYSE, } \\
\text { ASSESS }\end{array}$ & Walsh \& Linton (2001 & $\begin{array}{l}\text { Prahalad \& Hamel } \\
(1994) \\
\text { Marino (1996) } \\
\text { Tampoe (1994) } \\
\text { Yang et al (2006) }\end{array}$ & $\begin{array}{l}\text { Gallon et al (1995) } \\
\text { Harvey \& Lusch } \\
\text { (1997) } \\
\text { Javidan (1998) } \\
\text { Quelin (2000) }\end{array}$ \\
\hline
\end{tabular}


Table 1 Frameworks, models and methods from literature

\begin{tabular}{|c|c|c|c|}
\hline & Company & Industry Sector & Interviewee Role \\
\hline 1 & A & $\begin{array}{l}\text { Scientific \& industrial electrical } \\
\text { equipment } \\
\text { manufacturer/systems integrator }\end{array}$ & Manufacturing director \\
\hline 2 & B & Food process machinery & Manufacturing manager \\
\hline 3 & $\mathbf{C}$ & $\begin{array}{l}\text { Medical device, capital } \\
\text { equipment }\end{array}$ & Operations manager \\
\hline 4 & D & $\begin{array}{l}\text { Automotive components supplier } \\
\text { Large }\end{array}$ & Manufacturing director (Europe) \\
\hline 5 & $\mathbf{E}$ & Capital scientific equipment & Manufacturing director \\
\hline 6 & $\mathbf{F}$ & $\begin{array}{l}\text { Automotive supplier } \\
\text { Large }\end{array}$ & $\begin{array}{l}\text { General manager } \\
\text { (manufacturing) }\end{array}$ \\
\hline 7 & $\mathbf{G}$ & Industry centrifuge machinery & Joint managing director \\
\hline 8 & $\mathbf{H}$ & $\begin{array}{l}\text { Medical engineering } \\
\text { Large }\end{array}$ & Manufacturing manager \\
\hline 9 & $\mathbf{I}$ & $\begin{array}{l}\text { Medical equipment manufacturer } \\
\text { Large }\end{array}$ & Purchasing manager \\
\hline 10 & $\mathbf{J}$ & Machine tools & Managing director \\
\hline 11 & $\mathbf{K}$ & Pneumatic equipment & Supply manager \\
\hline 12 & $\mathbf{L}$ & $\begin{array}{l}\text { Capital equipment } \\
\text { (weighing/bagging) }\end{array}$ & Group managing director \\
\hline 13 & M & Commercial pump manufacturer & Senior operations manager \\
\hline 14 & $\mathbf{N}$ & $\begin{array}{l}\text { Industrial \& commercial \& } \\
\text { domestic products }\end{array}$ & Operations manager \\
\hline 15 & $\mathbf{O}$ & $\begin{array}{l}\text { Precision engineering \& } \\
\text { automotive } \\
\text { Large }\end{array}$ & Managing director \\
\hline 16 & $\mathbf{P}$ & Electric motors/pumps & Managing director \\
\hline
\end{tabular}

(Firms were SME in size unless where noted as Large)

Table 2 List of survey sample organisations 


\begin{tabular}{|c|c|c|}
\hline Question & Some Respondent Comments & Company \\
\hline \multirow[t]{5}{*}{$\begin{array}{l}\text { How would you define core } \\
\text { competencies? }\end{array}$} & $\begin{array}{l}\text { "competitive advantage, best in class } \\
\text { processes" }\end{array}$ & $\mathrm{D}$ \\
\hline & "unique skill or ability, cost and quality" & $\mathrm{F}$ \\
\hline & "competitive edge, what you are good at" & $\mathrm{H}$ \\
\hline & $\begin{array}{l}\text { "barrier to others, stop customers going } \\
\text { elsewhere" }\end{array}$ & L \\
\hline & $\begin{array}{l}\text { "a minestrone of many things, knowledge, } \\
\text { black art element in this business". }\end{array}$ & $\mathrm{P}$ \\
\hline \multirow{5}{*}{$\begin{array}{l}\text { Why do you believe that core } \\
\text { competencies are important to your } \\
\text { business? }\end{array}$} & "need to focus - not 'jack of all trades"' & $\mathrm{D}$ \\
\hline & "more efficiency, product focus" & $\mathrm{N}$ \\
\hline & "investment from the top" & $\mathrm{H}$ \\
\hline & "customer service" & B \\
\hline & "doing the right things" & $\mathrm{M}$ \\
\hline \multirow[t]{9}{*}{$\begin{array}{l}\text { What do you believe your core } \\
\text { competency is? }\end{array}$} & $\begin{array}{l}\text { "Hejunka - Japanese production levelling } \\
\text { manufacturing system" }\end{array}$ & $\mathrm{D}$ \\
\hline & $\begin{array}{l}\text { "knowledge of materials and machine } \\
\text { dynamics, process know-how" }\end{array}$ & G \\
\hline & $\begin{array}{l}\text { "UHV (ultra-high vacuum) knowledge and } \\
\text { technologies, carbon fibre processing skill" }\end{array}$ & $\mathrm{H}$ \\
\hline & "materials knowledge - superconductors" & I \\
\hline & $\begin{array}{l}\text { "engineering knowledge of weighing } \\
\text { technology, trade approvals knowledge, } \\
\text { materials feeding knowledge". }\end{array}$ & $\mathrm{L}$ \\
\hline & "ability to integrate manufacturing" & A \\
\hline & $\begin{array}{l}\text { "manufacture of a unique device, working } \\
\text { with titanium", }\end{array}$ & $\mathrm{C}$ \\
\hline & $\begin{array}{l}\text { "ability to manufacture world class magnet } \\
\text { technologies". }\end{array}$ & I \\
\hline & "Iow volume assembly" & $\mathrm{N}$ \\
\hline \multirow{9}{*}{$\begin{array}{l}\text { Do any of your competitors possess } \\
\text { core competencies similar or the same } \\
\text { as yours? }\end{array}$} & "yes" & A \\
\hline & "yes" & B \\
\hline & "yes" & $\mathrm{C}$ \\
\hline & "yes, pull system" & $\mathrm{D}$ \\
\hline & "not really" & E \\
\hline & "yes" & $\mathrm{F}$ \\
\hline & "no, we are unique" & G \\
\hline & "probably" & $\mathrm{H}$ \\
\hline & "yes" & $\mathrm{I}$ \\
\hline
\end{tabular}

Table 3 A sample of questions and answers regarding concept understanding 


\begin{tabular}{|c|c|}
\hline Number & Observation \\
\hline 1 & The survey sample consisted of 11 SME and 5 large sized firms. \\
\hline 2 & $\begin{array}{l}\text { The samples strategic business aims concentrated on profit and growth (not } \\
\text { longer term competitive advantage in their chosen market). }\end{array}$ \\
\hline 3 & $\begin{array}{l}\text { All sample firms quoted specialist knowledge as an element of core } \\
\text { competencies. }\end{array}$ \\
\hline 4 & $\begin{array}{l}\text { The sample firms quoted understanding customers as an element of core } \\
\text { competencies. }\end{array}$ \\
\hline 5 & $\begin{array}{l}\text { All sample firms quoted some element of manufacturing as a part of core } \\
\text { competencies. }\end{array}$ \\
\hline 6 & $\begin{array}{l}\text { S were slow in stating exactly what their defined core } \\
\text { gesting uncertainty. }\end{array}$ \\
\hline 7 & $\begin{array}{l}\text { le respondents believed that even basic manufacturing facilities and } \\
\text { nstituted core competencies. }\end{array}$ \\
\hline 8 & $\begin{array}{l}\begin{array}{l}\text { The sample respondents believed } \\
\text { competencies. }\end{array} \\
\text { comufacturing could provide }\end{array}$ \\
\hline 9 & $\begin{array}{l}\text { The sample respondents quoted core competencies were essentially those } \\
\text { things that firm was good at. }\end{array}$ \\
\hline 10 & $\begin{array}{l}\text { The sample respondents demonstrated a lack of understanding of core } \\
\text { competence characteristics, as defined within the literature. }\end{array}$ \\
\hline 11 & $\begin{array}{l}\text { re of sustainability, non-substitutability and other } \\
\text { core competency. }\end{array}$ \\
\hline 12 & $\begin{array}{l}\text { understanding as to why core } \\
\text { ed within the literature. }\end{array}$ \\
\hline 13 & $\begin{array}{l}69 \% \text { of all sample respondents suggest that the time taken to realise their stated } \\
\text { core competencies was 'many years' ( } 5 \text { and } 20 \text { years), whilst the remainder } \\
\text { were not able to answer. }\end{array}$ \\
\hline 14 & $\begin{array}{l}69 \% \text { of all sample respondents claimed to possess core competencies that were } \\
\text { rare amongst their competitors. }\end{array}$ \\
\hline 15 & $\begin{array}{l}81 \% \text { of all sample respondents believed that their stated core competencies } \\
\text { would be difficult but not impossible to imitate by competitors. }\end{array}$ \\
\hline 16 & $\begin{array}{l}69 \% \text { of all sample respondents accepted that their core competency based } \\
\text { competitive position could be threatened. }\end{array}$ \\
\hline 17 & $\begin{array}{l}50 \% \text { of all sample respondents believed there were aspects of their organisations } \\
\text { that were unique amongst their competitors. }\end{array}$ \\
\hline 18 & $\begin{array}{l}\text { All sample respondents' answers to the question about 'uniqueness' appear to } \\
\text { contradict their answers to earlier questions. }\end{array}$ \\
\hline 19 & $\begin{array}{l}\text { No sample respondent had used or was aware of the existence of core } \\
\text { competency related tools and techniques. }\end{array}$ \\
\hline
\end{tabular}

Survey sample $=16$ organisations (respondents)

Table 4 Observations derived from respondents answers 


\section{References}

Ahuja, I.Ps. and Khamba, J.S, Justification of total productive maintenance initiatives in Indian manufacturing industry for achieving core competitiveness, Journal of Manufacturing Technology Management, 2008, 19 (5), pp. 645-699.

Armstrong, C.E. \& Shimizu, K., A review of approaches to empirical research on the resource-based view of the firm, Journal of Management, 2007, 33 (6), pp. 959 - 986.

Baines, T., Kay, G., Sourcing for Competitive Manufacture, International Journal of Logistics Management, 2001, 81, 137-182.

Baker, J.C., Mapes, J., New, C.C. \& Szwejczewski, M., A hierarchical model of business competence, Integrated Manufacturing Systems, 1997, Vol.8, No.5, 265-272.

Barney, J., Firm Resources and Sustained Competitive Advantage, Journal of Management, 1991, 17, 99-120.

Bhamra, R. and Baines, T., Exploring the role of the core competency concept in noncorporate manufacturing organisations Proceedings of the $9^{\text {th }}$ International Conference European Operations Management Association, Copenhagen, 2002, 2-4 June, 127-138.

Bessant, J., Francis,D., Meredith, S., Kaplinsky, R. and Brown, S “Developing manufacturing agility in SMEs” International Journal of Technology Management 2001, 22, Numbers 1-3 , 28 - 54

Bogner, W.C., Thomas, H., McGee, J. Competence and Competitive Advantage: Towards a Dynamic Model, British Journal of Management, 1999, Vol.10, pp275-290.

Corbett, L.M., Campbell-Hunt, C., "Grappling with a gusher! Manufacturing's response to business success in small and medium enterprises", Journal of Operations Management, 2002, (20) 495-517.

Corbett, L.M., Manufacturing strategy, the business environment, and operations performance in small low-tech firms, International Journal of Production Research, 2008, 46 (20), pp 5491-5513.

Coyne, K.P., "Sustainable competitive advantage - what it is, what it isn't", Business Horizons, 1986, January - February, pp54-61.

De Meyer, A. \& Kim, J., Operations capabilities and strategic competencies: transform and leverage, 1996, INSEAD, Fontainbleau, France, (working paper).

De Toni, A., Tonchia, S., New production models: a strategic view, International Journal of Production Research, 2002, 40 (18), pp 4721-4741.

Gallon, M., Stillman, H. \& Coates, D., Putting core competency thinking into Practice, Research Technology Management, 1995, 38(3), pp494-503.

Gilgeous, V. \& Parveen, K., Core competency requirements for manufacturing effectiveness, Integrated Manufacturing Systems, 2001, Vol.12, No.3, 217-227.

Goddard, J., The architecture of core competence, Business Strategy Review, 1997, Vol.8, No.1, 43-52.

Grant, R.M., The Resource-based Theory of Competitive Advantage: Implications for Strategy Formulation, California Management Review, 1991, 34, Spring, 114-135. 
Hamel, G. \& Prahalad, C.K., Competing For The Future, 1994, Harvard Business School Press, USA.

Harvey, M. \& Lusch, R., Protecting the core competencies of a company: intangible asset security, European Management Journal, 1997, Vol.15, No.4, 370-380.

Hayes, R.H. \& Wheelwright, S.C., The Dynamics of Process-Product Life Cycles, Harvard Business Review, 1979, March-April, 127-136.

Hayes, R.H. \& Wheelwright, S.C., Restoring Our Competitive Edge: Competing Through Manufacturing, 1984, John Wiley \& Sons, New York, NY.

Javidan, M., Core Competence: What Does it Mean in Practice? Long Range Planning, 1998, 31(1), 60-71.

Kay, J.A. Foundations of Corporate Success, 1993, Oxford University Press, Oxford.

Kim, J. \& Arnold, P., Manufacturing Competence and Business Performance: A framework and Empirical Analysis, IJOPM, 1992, 13(10), 4-25.

Lagace, D., Bourgault, M., "Linking manufacturing improvement programs to the competitive priorities of Canadian SMEs", Technovation, 2003, (23) 705-15.

Marino, K.E., Developing consensus on firm competencies and capabilities, Academy of Management Executive, 1996, Vol.10, No.3, 40-51.

Miles, M.B. and Huberman, A.M, Qualitative data analysis: an expanded sourcebook, 1994, Sage Publications, Thousand Oaks, California.

Mills, J. and Platts, K., Applying resource-based theory: methods, outcomes and utility for managers, Proceedings of the $8^{\text {th }}$ International Conference European Operations Management Association, 2001, Bath, 177-190.

Mills, J., Platts, K., Bourne, M., Competence and resource architectures, International Journal of Operations \& Production Management, 2003, 23 (9), pp 177-190

Newbert, S.L., Value, rareness, competitive advantage and performance: a conceptual-level empirical investigation of the resource-based view of the firm, Strategic Management Journal, 2008, 29 (2), pp. 745 - 768.

Penrose, E. The Theory of the Growth of the Firm, 1959, John Wiley \& Sons, New York.

Peteraf, M., The Cornerstone of Competitive Advantage, Strategic Management Journal, 1993, 14, 179-191.

Petts, N., Building Growth on Core Competencies - a Practical Approach, Long Range Planning, 1997, 30(4), 551-561.

Porter, M., Competitive Strategy: Techniques for Analysing Industries and Competitors, 1980, Free Press, New York.

Prahalad, C.K., \& Hamel, G., The Core Competence of the Corporation, Harvard Business Review, 1990, May-June, 71-91.

Quelin, B., Core competencies, R\&D management and partnerships, European Management Journal, 2000 Vol.18, No 5, 476-487. 
Reiner, G., Demeter, K., Poiger, M.,\& Jenei, I., The internationalisation process in companies located at the borders of emerging and developed countries, International Journal of Operations \& Production Management, 2008, 28 (10), pp 918-940.

Robson, C., Real World Research: A Resource for Social Scientists and Practitioners, 1993, Blackwell Publishers, MA, USA,

Rumelt, R., Toward a Strategic Theory of the Firm, In: R.Lamb (Ed), Competitive Strategic Management, 1984, 556-570.

Savory, C., Translating knowledge to build technological competence, Management Decision, 2006, 44 (8), pp.1052 - 1075.

Scarborough, H., Path(ological) Dependency? Core Competencies from an Organisational Perspective, British Journal of Management, 1998, 9, 219-232.

Schroeder, R.W., Anderson, J.C. and Clevelend, G. The Content of Manufacturing Strategy: An Empirical Study, Journal of Operations Management, 1986, 6(4), 405-415.

Selznick, P., Leadership in Administration, 1957, New York, Harper \& Row.

Stalk, G., Evans, P. and Shulman, L., Competing on Capabilities: the new rules for corporate strategy, 1992, Harvard Business Review, March/April, 45-62.

Tampoe, M., Exploiting the core competencies of your organisation, Long Range Planning, 1994, Vol.27, No.4, 66-77.

Vickery, S.K., A Theory of Production Competence Revisited, Decision Sciences, 1993, 22, 635-643.

Walsh, S.T. \& Linton, J.D., The competence pyramid: a framework for identifying and analysing firm and industry competence, Technology Analysis \& Strategic Management, 2001, Vol.13, No.2, 165-177.

Wernerfelt, B., A Resource-based View of the Firm, Strategic Management Journal, 1984, 5, 171-180.

Winterschied, B.C., Building capability from within: the insiders' view of core competence, in Hamel G. and Heene (Eds), Competence Based Competition, 1994, John Wiley \& Sons Ltd., England.

Yang, B., Wu, B., Shu, P. \& Yang, M., On establishing the core competency identifying model, Industrial Management \& Data Systems, 2006, 106 (1), pp. 60-80.

Yeung, A., Lai, K. \& Yee, R., Organisational learning, innovativeness, and organisational performance: a qualitative investigation, International Journal of Production Research, 2007, 45 (11), pp 2459-2477.

Zhang, Q., \& Vonderembse, M.A., Value chain flexibility: a dichotomy of competence and capability, International Journal of Production Research, 2002, 40 (3), pp 561-583. 